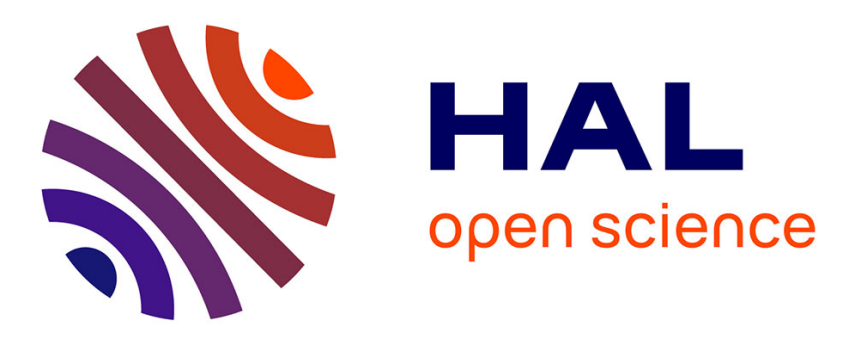

\title{
Adolescent idiopathic scoliosis young female rib hump: normative biomechanical data study
}

Jean-Philippe Berteau, Philippe Lasaygues, Martine Pithioux, Patrick

Chabrand

\section{- To cite this version:}

Jean-Philippe Berteau, Philippe Lasaygues, Martine Pithioux, Patrick Chabrand. Adolescent idiopathic scoliosis young female rib hump: normative biomechanical data study. Computer Methods in Biomechanics and Biomedical Engineering, 2011, 14 (sup1), pp.47-48. 10.1080/10255842.2011.591633 . hal-01296918

\section{HAL Id: hal-01296918 \\ https://hal.science/hal-01296918}

Submitted on 29 Nov 2018

HAL is a multi-disciplinary open access archive for the deposit and dissemination of scientific research documents, whether they are published or not. The documents may come from teaching and research institutions in France or abroad, or from public or private research centers.
L'archive ouverte pluridisciplinaire HAL, est destinée au dépôt et à la diffusion de documents scientifiques de niveau recherche, publiés ou non, émanant des établissements d'enseignement et de recherche français ou étrangers, des laboratoires publics ou privés. 


\title{
Adolescent idiopathic scoliosis young female rib hump: normative biomechanical data study
}

\author{
J.-Ph. Berteau ${ }^{\mathrm{a} *}, \mathrm{Ph}$. Lasaygues $^{\mathrm{b}}$, M. Pithioux ${ }^{\mathrm{a}}$ and P. Chabrand ${ }^{\mathrm{a}}$ \\ ${ }^{a}$ Institut des Sciences du Mouvement E.J.Marey Equipe GIBO, Institute of Movement Sciences, ISM-UMR 6233 CNRS/Université de la \\ Méditerranée, 163 Avenue de Luminy, Case Postale 918, 13288 Marseille Cedex 09, France; ${ }^{b}$ Laboratoire de Mécanique et d'Acoustique \\ Equipe PI, Unité Propre du CNRS - UPR 7051, 31, Chemin Joseph-Aiguier, 13402 Marseille Cedex 20, France
}

Keywords: scoliosis; ribs; elastic properties

\section{Introduction}

In adolescent idiopathic scoliosis (AIS), several investigations (Lee et al. 2005; Lam et al. 2011) demonstrated that low bone mineral density (BMD) is a systematic disorder in AIS which can be persistent. In a biomechanical view, a low BMD is associated with low bone strength. To our knowledge, in the case of scoliotic rib, no specific mechanical data are available to model scoliotic rib cage (Descrimes et al. 1995). From human surgery wastes (gibbectomy), cortical part of scoliotic ribs has been tested using an ultrasonic device to get elastic properties (Young's modulus, Poisson's ratio); CT scan has been used to get BMD added to an histomorphometric analysis to evaluate the porosity of the cortical area. The aim of this study was to provide normative mechanical data for ribs, components of the rib hump, by establishing BMD and elastic properties associated with histomorphometric observation. This study offers normative biomechanical information of scoliotic ribs and leads us to use these data in AIS rib cage finite element modelling

\section{Methods}

Two patients (F15 and F17, respectively, female of 15 and 17 years old) with severe deformities (more than $40^{\circ}$ of Cobb angle) were treated to correct the rib hump deformity and 4 or 5 parts of these ribs were extracted. After the cutting process, the proximal part (1 cm length) of each rib was embedded in methyl methacrylate, which allows a histomorphometric evaluation with Image ${ }^{\circledR}$ providing the porosity and the osteonal orientation. A CT scan was carried out on sticks designed in the remaining part, and on phantoms (Cirs 62) containing various concentrations of hydroxyapatite (HA; 200, 800, 1000, 1250 and $1750 \mathrm{mg} / \mathrm{cm}^{3}$ ). This process allows to relate the CT Hounsfield units (HU) to mineral content (linear equation). Rectangular region of interests determined on each sample, with Mimics ${ }^{\circledR}$ (Materialise NV), leads to their own BMD (matrix $512 \times 512$ pixel size $215 \mu \mathrm{m}$ in the cut plane). A specific ultrasound device (Figure 1), which is able to study a small sample, has been designed to obtain transversal and longitudinal velocities (VLs) using $7 \mathrm{MHz}$ transducer. In the longitudinal direction and if the density values are known, it is possible to get Young's modulus.

\section{Results and discussion}

Porosity of cortical part is lower than $2.18 \%$. Medium value is $1.35 \%$ with a standard deviation of 0.52 . Tissue morphology of AIS ribs cross section shows a usual adult cortical bone morphology, lamellar and osteonal organisation. Each sample can be considered as non-porous material, thus to calculate the longitudinal Young's modulus $E$, we can use the following equation:

$$
E=\rho \times v^{2}
$$

where $\rho$ is the sample density and $v$ the longitudinal wave velocity.

Upon condition that the wavelength of the ultrasonic wave used $(0.22 \mathrm{~mm})$ was 10 times lower than slides thickness.

Owing to the curve of each rib of the rib hump, seven rectangular samples were cut from F15's ribs and eight from F17. The linear equation obtained with HA phantom, $\left(\mathrm{BMD}=0.8565 \mathrm{HU}+224.23 ; R^{2}=0.991\right)$ leads us to an average value of $2204 \mathrm{mgHA} \mathrm{cm}^{-3}$ for $\mathrm{F} 15$ and 2500 for F17. These values of BMD are original, to our knowledge there is no similar data in the literature.

For the F15's ribs samples, average VL is $2575 \mathrm{~m} / \mathrm{s}^{-1}$ (ranged from 2079 to $3103 \mathrm{~m} / \mathrm{s}^{-1}$ ) and average value for transversal velocity (VT) is $1660.62 \mathrm{~m} / \mathrm{s}^{-1}$ (ranged from 1598 to $1746 \mathrm{~m} / \mathrm{s}$ ). Considering the F17's ribs, average VL: $2711 \mathrm{~m} / \mathrm{s}^{-1}$ (ranged from 1799 to $3516 \mathrm{~m} / \mathrm{s}$ ); average VT: $1796 \mathrm{~m} / \mathrm{s}^{-1}$ (ranged from 1576 to $2009 \mathrm{~m} / \mathrm{s}$; Figures 2 and 3$)$.

\footnotetext{
*Corresponding author. Email: jean-philippe.berteau@univmed.fr
} 


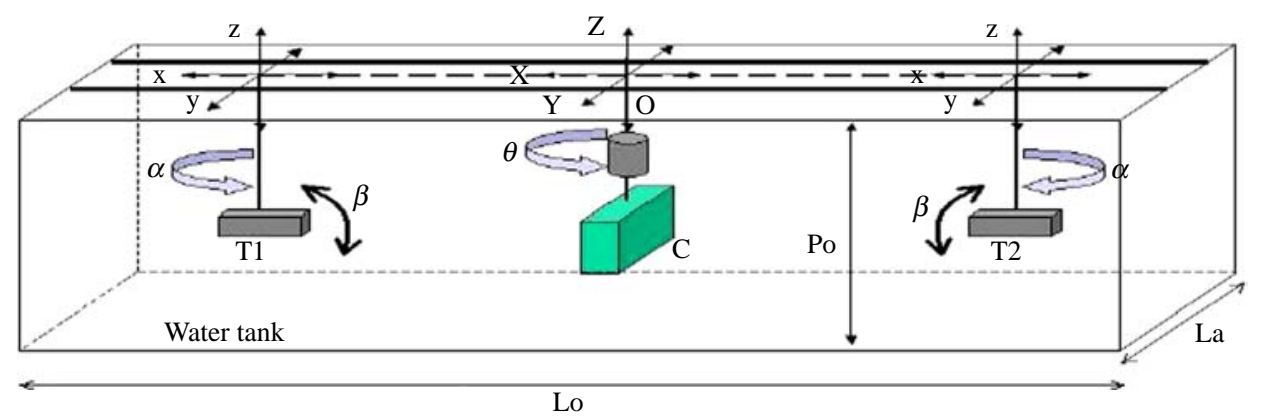

Figure 1. Acoustic bench (7 MHz).

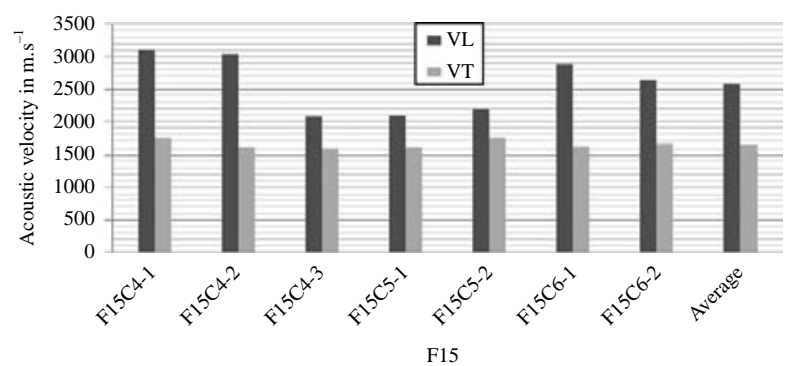

Figure 2. Acoustic velocity values for 15 year old females. $(C i-j$; rib number: $i$ and sample number: $j$ ).

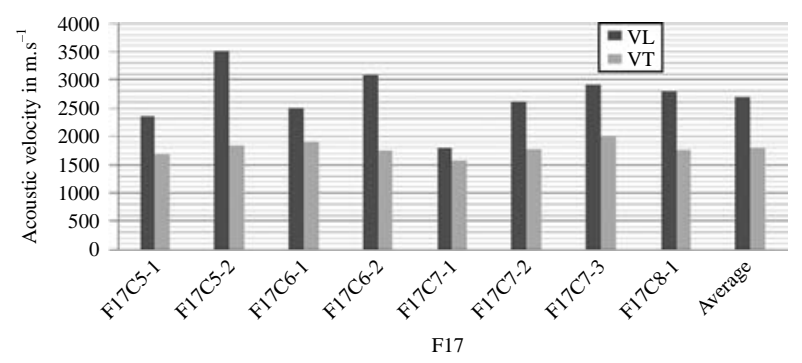

Figure 3. Acoustic velocity values for 17 year old females. ( $C i-j$; rib number: $i$ and sample number: $j$ ).

Literature data for cortical part of human bone are $2700-3800 \mathrm{~m} / \mathrm{s}$ (Katz et al. 1984) and $3550-4180 \mathrm{~m} / \mathrm{s}$ (Yoon and Katz 1976), though to our knowledge, there is no human ribs evaluated using ultrasonic experimentation. Considering the Young modulus, E3 average value for F15 and F17 was, respectively, $12.1 \pm 4.3$ and $13.5 \pm 2.5 \mathrm{GPa}$. These data are far away from the value $(5 \mathrm{GPa}$; Descrimes et al. 1995) used in most of the finite element model of scoliosis. Though it is a value for cortical and trabecular part and from a study of a global vertebro-costal complex. In accidentology, the ribs Young's modulus correponds to a global value for a whole bone. That is why we cannot compare with normal young female cortical rib samples, and the lack of reference in paediatric population bone's data leads us to consider these as a reference.

\section{Conclusions}

This study gives an experimental ultrasonic scan and CT scan evaluation which provides normative data of cortical sample from scoliotic ribs. Models of spinal scoliotic deformity optimise brace or surgical treatment, their reliability is an important issue of biomechanical modelling; these new data could lead to improve their biofidelity. Evaluating the sensibility of mechanical properties could lead to a new numerical experimentation process. A new goal could be to analyse anisotropy by determining with other mechanical tests (such as compression) the Young modulus in other directions.

\section{Acknowledgements}

We thank the INSERM U831 for their collaboration and help in histological evaluation and to the Timone's Hospital (Pr Bollini) for bone samples. The donors or their legal guardians provided informed written consent for donating their tissues for investigation in accordance with legal clauses stated in the French Code of Public Health and approved by the Committee for the Protection of Person.

\section{References}

Descrimes JL, Aubin CE, Skalli W et al., 1995. Modelling of facet joints in a finite element model of the scoliotic spine and thorax: mechanical aspects. Rachis. 7(6): $301-314$.

Katz JL, Yoon HS, Lipson S, Maharidge R, Meunier A, Christel P. 1984. The effects of remodeling on the elastic properties of bone. Calcif Tissue Int. 36(Suppl 1):S31-S36.

Lam TP, Hung VW, Yeung HY, Tse YK, Chu WC, Ng BK, Lee KM, Qin L, Cheng JC. 2011. Abnormal bone quality in adolescent idiopathic scoliosis: a case-control study on 635 subjects and 269 normal controls with bone densitometry and quantitative ultrasound. Spine. 36(15): 1211-1217.

Lee WT, Cheung CS, Tse YK, Guo X, Qin L, Lam TP, Ng BK, Cheng JC. 2005. Association of osteopenia with curve severity in adolescent idiopathic scoliosis: a study of 919 girls. Osteoporos Int. 16(12):1924-1932.

Yoon HS, Katz JL. 1976. Ultrasonic wave propagation in human cortical bone-I. Theoretical considerations for hexagonal symmetry. J. Biomech. 9:407-412. 